\title{
“DIPLOMACIA DO PÉ": o Brasil e as competições esportivas sul-americanas de 1919 e 1922
}

\author{
João Manuel Casquinha Malaia Santos*
}

\section{Resumo}

O presente artigo pretende discutir o papel das primeiras competições esportivas internacionais sediadas no Brasil, em 1919 e 1922, nas relações internacionais do país. Através da análise da política externa, das ações diplomáticas e da repercussão desses eventos pela imprensa, dentro e fora do país, pretende-se trazer uma primeira aproximação para o entendimento desses eventos como marcos importantes, tanto para a trajetória do país como sede de competições esportivas internacionais, quanto da própria política externa brasileira.

Palavras-chave: Esportes. Primeira República. Relações Internacionais.

\section{O Espírito Americano}

- Veja, amigo, que nós estamos dando licções à velha Europa. Enquanto elles lá resolvem as suas questões nos campos de batalhas, nós aqui, resolvemolas nos campos... de foot-ball...

(Fon-Fon, Ano XIII, n. 20, 17 de maio de 1919, p. 39.)

A frase citada acima é a legenda de uma ilustração feita por Seth para a revista FonFon, uma das mais populares do Rio de Janeiro no início do século XX, com circulação nacional e internacional. Na imagem, dois rapazes conversam em tom amigável, e um deles mostra ao outro como a América dava lições à “velha” Europa. Em maio de 1919, enquanto na Europa, em Versalhes, as potências e países de menor projeção no cenário internacional (como o Brasil, por exemplo) impunham um violento tratado à Alemanha no Conselho da

*Professor do Programa de Pós-Graduação em História Comparada do Instituto de História - UFRJ - onde desenvolve projeto de pós-doutorado com o título: "Esporte e Economia: O Rio de Janeiro e as Competições Esportivas Internacionais” com financiamento FAPERJ. E-mail: jmalaia@gmail.com 
Liga das Nações, no Brasil, no Rio de Janeiro, disputava-se um campeonato sul-americano de futebol entre as seleções brasileira, argentina, chilena e uruguaia. Na América do Sul, os países faziam, portanto, a chamada "diplomacia do pé”. 1

Ao final da I Guerra Mundial, o quadro geopolítico internacional se ajustava a novos contextos, e a formação de um órgão supranacional para organizar e reordenar as velhas e novas forças nacionais foi a solução adotada pelos principais chefes de Estado do mundo com o objetivo de evitar novos conflitos entre as nações. A fundação da Liga das Nações, bem como a definição dos membros permanentes e temporários de seu órgão decisório máximo, o Conselho, eram os pontos mais importantes na agenda internacional. Tal Conselho foi formado com quatro membros permanentes (Inglaterra, França, Itália e Japão) e quatro temporários. Brasil e Uruguai se apresentaram como candidatos representantes da América ao posto temporário, uma vez que o congresso norte-americano havia vetado a participação de seu país no órgão.

Tornava-se necessário mostrar ao mundo, por meio de ações significativas que se projetassem pelo mundo, a preponderância do Brasil nesta parte do continente. Em 1919, o Brasil foi nomeado para uma cadeira temporária do Conselho, ao lado de Bélgica, Grécia e Espanha. Em 22 de setembro de 1922, o Conselho aumentou o número de postos temporários para seis, dando ao Brasil uma situação confortável na manutenção de sua cadeira, minimizando, no entanto, a possibilidade de o país ocupar o posto de membro permanente.

Nesses mesmos anos críticos da política internacional, principalmente para as questões ligadas à ingerência dos países sul-americanos no novo quadro geopolítico internacional, o Brasil teve a oportunidade de ser sede de vários eventos internacionais, principalmente sediados na cidade do Rio de Janeiro, capital do país. O principal deles foi a Exposição Internacional de 1922, durante as comemorações do centenário da independência do país. Nesse mesmo ano, além da Exposição, uma série de outras iniciativas foi organizada por diferentes agentes sociais em celebração à simbólica data, incluindo os Jogos Olímpicos SulAmericanos, uma competição esportiva com a chancela do Comitê Olímpico Internacional (COI), em que as seleções sul-americanas filiadas a este órgão disputavam quase todas as modalidades esportivas apresentadas nos Jogos Olímpicos disputados em 1920, em Paris.

A competição fez parte da programação oficial dos festejos do centenário organizados pelo governo e tiveram grande repercussão nacional e internacional. O campeonato de futebol

\footnotetext{
${ }^{1}$ Um artigo da revista carioca Careta afirmava que enquanto a Europa fazia a diplomacia das armas, "a América do Sul, a correr atráz de uma bola, faz a diplomacia do pé”. O FOOT-BALL. Careta, Rio de Janeiro, Ano XII, n. 569, 17 mai., 1919, p. 8.
} 
foi disputado no estádio do Fluminense Football Club, uma das maiores praças esportivas da América do Sul, com capacidade para pelo menos 22 mil pessoas.

O sucesso da competição não se deu apenas devido às celebrações do centenário da independência. Não podemos negar que eventos como a Exposição Internacional impulsionaram o sucesso das competições esportivas. Porém, o fanatismo de boa parte dos cariocas com o futebol já vinha sendo demonstrado nos campeonatos que se realizavam na cidade desde o início do século XX e com alguns jogos da seleção brasileira de futebol, organizados pela Confederação Brasileira de Futebol (CBD) desde 1916. Momento decisivo no processo de envolvimento da instituição "seleção brasileira de futebol” com a sociedade foi demonstrado no IV Sul-Americano de Futebol de 1919, também disputado no estádio do Fluminense, construído especialmente para abrigar esta, que foi a primeira competição internacional esportiva sediada no Brasil oficializada por uma entidade sul-americana, no caso a Confederação Sul-Americana de Futebol (CSF).

A imprensa do Rio de Janeiro e de São Paulo deu grande destaque ao campeonato e podemos considerar que foi então que este esporte passou definitivamente para a esfera dos interesses tanto da política interna, quanto externa do país. ${ }^{2} \mathrm{O}$ discurso dos representantes do Estado brasileiro de que o Brasil, como representante da América no Conselho da Liga, era uma nação que lutaria por propósitos pacíficos no mundo pós--guerra, discurso que gerou o conceito de "cordialidade oficial da diplomacia brasileira”3 (CERVO, 2008, p. 19), foi transportado para os cronistas que escreviam sobre os jogos, ou pelos ilustradores, que com suas charges e caricaturas analisavam as relações internacionais do país através da competição daquele ano, como vimos na publicação de Seth.

O que se propõe com esse tema é uma pesquisa sobre a história dessas duas competições esportivas já sediadas no Brasil e um diálogo com alguns conceitos das Relações Internacionais. Pretende-se mostrar um panorama da política de relações internacionais do Brasil por intermédio da participação e organização de competições esportivas internacionais, principalmente as primeiras competições esportivas internacionais disputadas no país: os campeonatos sul-americanos de futebol, natação e water-polo, em 1919, e os Jogos SulAmericanos, em 1922.

\footnotetext{
${ }^{2}$ Em relação à competição sul-americana de 1919, Cf. FRANZINI (2003), PEREIRA (2000) e SANTOS (2010).

${ }^{3}$ Segundo Amado L. Cervo, tal conceito seria um dos mais fortes no pensamento dos agentes da política externa brasileira e estaria pautado em um discurso que exaltasse "a grandeza do país, a convivência necessária, a prosperidade que a todos interessa, a boa imagem a cultivar em razão dos efeitos que exerce sobre a opinião e os dirigentes, a paz a manter, a tranqüilidade das fronteiras". Tal atitude induziria a "uma conduta em que sobressai a ação cooperativa em vez do confronto, a humildade em vez da empáfia política, a negociação em vez da ostentação de força”. (CERVO, 2008, p. 19)
} 
Parte-se de uma hipótese central: os eventos esportivos internacionais são poderosos instrumentos de alcance social e de projeção internacional. A partir dessa ideia, pretende-se mostrar como algumas premissas do pensamento da política externa brasileira podem ser percebidas tanto nos discursos dos agentes do poder (estatal e esportivo), quase sempre de maneira a enquadrar tais eventos dentro de um discurso mais amplo das relações internacionais do país, quanto nas narrativas sobre o evento, feitas por jornalistas ligados à grande imprensa paulista e carioca, nem sempre alinhadas com o discurso proferido pelos primeiros. Com o foco da análise nas competições de 1919 e 1922, procura-se mostrar, neste trabalho, como tais eventos, disputados em momentos cruciais da política internacional, podem e devem ser observados a partir do prisma das relações internacionais.

Para o desenvolvimento desta pesquisa, dividiu-se o trabalho em quatro etapas relacionadas também a alguns de seus objetivos: trabalhar os conceitos mais relevantes relacionando a história dos esportes e as relações internacionais; mostrar a pluralidade de fontes para este tipo de análise; caracterizar efetivamente as competições como aspectos relevantes das relações internacionais e abrir novas perspectivas para os estudos nessa área. Na primeira parte, trabalha-se alguns conceitos importantes para a análise das competições esportivas internacionais como aspecto relevante das relações internacionais. Tal abordagem tem como objetivos mostrar os esportes como importantes ferramentas das relações internacionais e apresentar alguns conceitos que podem ser utilizados em futuras pesquisas sobre o tema, além de evidenciar, também, a natureza das fontes recolhidas e fazer sua classificação e análise crítica, para posteriormente abordar os métodos utilizados para o trabalho com tal material. Na segunda e terceira partes, faz-se uma reconstituição dos eventos de 1919 e 1922, respectivamente, a partir dos conceitos trabalhados anteriormente e apoiado nas fontes e métodos apresentados.

As competições esportivas internacionais, a globalização e as relações internacionais

Para esta pesquisa encaram-se as competições esportivas internacionais como expressão das relações internacionais entre os países. Deve-se ter em conta o grande destaque dado a elas pelo Estado, pelos meios de comunicação e pelos espectadores, que as transformam em espetáculo, “a representação diplomática da sociedade hierárquica perante si própria” (DEBORD, 2003, p. 21). 
Para a análise das competições esportivas internacionais, não se pode deixar de pensar o conceito de relações internacionais de um modo mais amplo, para além da política externa e da diplomacia. Tratar-se-á o conceito das relações internacionais segundo as proposições de Amado Luiz Cervo, i.e., como um fenômeno em que se imbricam três agentes: a diplomacia, o governo e sua política, e a sociedade com suas forças, que se relacionam entre si e se influenciam reciprocamente.

Assim as forças sociais que espelham o grau de desenvolvimento econômico, como a apropriação de conhecimento científico, a inovação tecnológica, a organização empresarial e a concentração de capital, mas que também espelham outros fatores como a geografia, a densidade demográfica, a cultura, a opinião pública e o sentimento nacional, relacionam-se com a política exterior, uma vez que a sociedade organizada pretende alcançar objetivos transnacionais (CERVO, 2008, p. 11).

No entanto, há uma peculiaridade em relação às competições esportivas internacionais como expressão mais ampla das relações internacionais: em tais eventos, esportistas extremamente talentosos, nascidos em países de pouca expressão no cenário da política internacional, conseguem resultados notórios em provas ou jogos de grande interesse entre boa parte da população. Dessa maneira, essas nações têm a oportunidade de ter grande projeção internacional, motivo pelo qual alguns governos investem altas somas na formação de atletas de alto nível em determinados esportes.

De qualquer forma, mesmo com a projeção de países de menor status na geopolítica internacional, tais feitos, isolados em determinadas conquistas em alguns esportes, acabam por reforçar a hierarquia entre os países, quando comparados aos resultados esportivos conquistados pelas grandes potências mundiais. ${ }^{4}$

Além dos resultados, as nações que conseguem sediar grandes eventos esportivos, usam-nos como instrumento de propaganda, interna e externa, ao alcance de metas econômicas sólidas que caracterizem a pujança, principalmente econômica, dos países-sede. Os Estados aproveitam-se dessa projeção internacional para dinamizar suas relações

\footnotetext{
${ }^{4}$ Para se ter uma ideia, nas últimas Olimpíadas de Pequim, enquanto a Jamaica obteve seis medalhas de ouro, em apenas uma modalidade (atletismo), em corridas de curta distância, a China, primeira colocada na classificação por medalhas de ouro, ganhou 51 medalhas em 18 modalidades diferentes e os EUA, segundo colocado, obtiveram 36 medalhas em 15 modalidades diferentes. No entanto, excluindo os EUA, a Jamaica foi a primeira colocada em medalhas de ouro entre os países americanos, ficando em $13^{\circ}$ lugar no geral. O país americano mais próximo da Jamaica foi Canadá, em $19^{\circ}$, com três medalhas de ouro, em três modalidades diferentes. No entanto, o Canadá teve um total de 18 medalhas (três de ouro, nove de prata e seis de bronze) em 10 modalidades diferentes, já a Jamaica obteve apenas 11 medalhas (seis de ouro, três de prata e duas de bronze) todas em provas de atletismo e em corridas de curta distância. Tais resultados mostram que os investimentos em esporte na Jamaica visam priorizar as provas em que seu país mais se destaca em detrimento de outras.
} 
internacionais para além do campo dos esportes e catalisam investimentos no setor de turismo, transportes e meios de comunicação, além daqueles em infra-estrutura para receber os jogos e do prestígio internacional.

Ao mesmo tempo em que o processo de globalização traz uma nova série de matizes e de analistas de plantão que dão tintas de uma sociedade sem fronteiras e pós-industrial a este processo, as competições esportivas internacionais, com a participação de seleções que almejam representar seus países, trazem uma das poucas possibilidades concretas e de notória visibilidade das nações se congregarem e darem aos espectadores oportunidades de se sentirem pertencentes a um grupo definido de pessoas que habitam o mesmo espaço físico delimitado por fronteiras, comungam de uma mesma língua e que torcem por aquele grupo de esportistas que carregam as bandeiras de suas “comunidades”. Nesse caso, o conceito de nação apresentado por Benedict Anderson, parece bastante apropriado para se pensar as relações internacionais do esporte. Segundo o autor, as nações seriam “comunidades imaginadas”, pois as pessoas pertencentes a uma determinada nação se sentem pertencentes a uma comunidade que comunga dos mesmos hábitos culturais. No entanto, uma nação comporta um número elevado de habitantes que em sua maioria não se conhecem. Portanto, as pessoas imaginam pertencerem a uma mesma comunidade, à nação, e os gestores do Estado precisam constantemente desenvolver mecanismos que alimentem esse imaginário de pertencimento a uma mesma comunidade (ANDERSON, 2005).

Os gestores do Estado criaram e continuam criando, ou recriando, mecanismos que gerem vínculos de interdependência entre aqueles que pertencem a uma determinada nação, bem como de pertencimento a uma ordem geral global, o que auxilia, sobremaneira, a concepção da nação como valor supremo. O aumento do número de conflitos e das tensões entre os diversos Estados não são os únicos fatores a colocarem as nações, organizadas como Estados, em primeiro plano.

Torna-se necessário ver o outro como diferente, estabelecer comparações em diversos níveis, para enxergar as diferenças nos outros e as semelhanças entre os membros dessa comunidade tão ampliada que se tornou a nação. A guerra foi um dos mecanismos que mais impulsionaram sentimentos de exacerbação da nação no século XX. Para evitar os conflitos, ou organizá-los, foram criadas instituições supranacionais, nas quais os representantes dos Estados negociavam seus interesses e mostravam o alcance de sua influência na política internacional.

Instituições como a Liga das Nações, no início do século, e a Organização das Nações Unidas, desde o final da Segunda Grande Guerra, passaram a ter nos representantes do Estado 
figuras que falavam em nome da nação nas questões discutidas nos conselhos desses órgãos, um dos principais palcos de atuação da política externa dos países.

A formação de órgãos de administração dos esportes em nível supranacional (algo que, diga-se de passagem, ocorreu bem antes das instituições acima citadas) tem estrita relação com o contexto da organização global do mundo e acompanha de maneira exemplar a ideia de Gramsci sobre a formação das entidades gestoras de determinados aspectos relevantes nas sociedades contemporâneas. Segundo o intelectual italiano,

os órgãos deliberativos tendem cada vez mais a diferenciar sua atividade em dois aspectos "orgânicos": o deliberativo, que lhes é essencial, e o técnicocultural, onde as questões sobre as quais é preciso tomar resoluções são inicialmente examinadas por especialistas e analisadas cientificamente. Esta atividade já criou todo um corpo burocrático de nova estrutura, pois além dos escritórios especializados de pessoas competentes, que preparam o material técnico para os corpos deliberativos, cria-se um segundo corpo de funcionários, mais ou menos "voluntários" e desinteressados, escolhidos de vez em quando na indústria, nos bancos, nas finanças. (GRAMSCI, op. cit., p. 119)

Desse modo, grupos das camadas mais abastadas das grandes cidades do mundo não só tomavam para si o controle dos esportes, em nível municipal, estadual e nacional, mas também costuravam suas alianças com outros grupos da elite de outros países para a gerência dos esportes em níveis continentais e mundiais. Órgãos como a Federation Internationalle de Football Association (FIFA) e o COI conseguem estabelecer lógicas próprias de distribuição de poder e originam verdadeiras dinastias no comando de tais instituições. ${ }^{5}$

Através da organização de competições esportivas mundiais, como a Copa do Mundo de Futebol e os Jogos Olímpicos, os chamados valores ocidentais são expostos à exaustão para todo o planeta pelos meios de comunicação. Por meio de um discurso de “jogo limpo”, ou fair play, e de espírito olímpico, tais eventos oferecem uma oportunidade singular para a reverberação de valores legitimadores de uma nova ordem internacional, tendo os esportes e seus valores como esteios.

As grandes competições esportivas são, ao mesmo tempo, reprodutoras do sistema capitalista, possibilidade de apropriação e exploração de trabalho, mecanismos de acumulação de capital, e propagadoras de ideais ligados ao liberalismo, à competitividade perante a

\footnotetext{
${ }^{5}$ Para se ter uma idéia, apenas citando os presidentes que ficaram mais de dez anos no poder, temos na FIFA: Daniel Burley Woolfall, inglês (1906 a 1918); Jules Rimet, francês (1921 a 1954), Stanley Rous, inglês (1961 a 1974); João Havelange, brasileiro (1974 a 1998) e o atual presidente Joseph Blatter, suíço (desde 1998). No COI, os presidentes que mais tempo permaneceram no poder foram: Pierre de Coubertain, francês (1896 a 1925); Henri de Baillet-Latour, belga (1925 a 1942); Avery Brundage, norte-americano (1952 a 1972); Juan Antonio Samaranch, espanhol (1980 a 2001) e o atual presidente, Cout Jacques Rogge, belga (desde 2001).
} 
igualdade das regras e à justiça, materializada, por exemplo, na figura do árbitro. Mas também são espaços para confrontos de nações, possibilidade aberta para a projeção de símbolos nacionalistas, xenófobos, racistas e que, em alguns casos, acabam causando até mesmo problemas diplomáticos entre países. Houlihan (1994, p. 20) identificou cinco possíveis temas para discussão do esporte relacionado às Relações Internacionais: como um veículo para a diplomacia, para a ideologia, para a construção da nação, para o acesso à arena internacional e para ganhos comerciais.

Poder-se-á verificar, ao longo deste artigo, uma série de ações diplomáticas, medidas tomadas por membros do governo, além de um sem número de "forças sociais" que agem em torno das grandes competições esportivas sediadas no Rio de Janeiro.

Para este trabalho, torna-se necessário estar atento ao contexto político e aos discursos construídos em torno dos eventos, da seleção brasileira e de seus jogadores como encarnação da nação e das possibilidades de relações políticas, econômicas e culturais com outros países do mundo no momento em o Brasil foi a sede de grandes eventos esportivos internacionais.

Apesar da temática do esporte estar cada vez mais presente nas pesquisas historiográficas nos últimos anos, como se verá ao longo deste artigo, inúmeros outros artigos colocaram os eventos esportivos internacionais como importante ferramenta no tabuleiro das relações internacionais. Tais estudos concentram-se em publicações fora do país ${ }^{6}$ e têm-se mostrado reveladores de possibilidades bastante interessantes para investidas no tema em relação ao Brasil.

Chistopher Hill, no prólogo de uma das obras que relacionam esportes e relações internacionais, ${ }^{7}$ assim aborda as possibilidades de pesquisa neste campo:

Since international relations, by definition, are wider than 'international politics' they automatically incorporate all cross-border activities, even those of a purely functional kind. The interesting questions about sport or other forms of civil association, however, relate to its impact on things out-side itself, which in the context means the character and evolution of the international system. [...] Apart from the clichés about sport either embodying national rivalries or providing a safety-valve for them, there are serious issues to research such as the role of sport in nation-building,

\footnotetext{
${ }^{6}$ Para artigos que relacionem os Jogos Olímpicos com questões das relações internacionais, Cf. DINCES, Sean. Padres on Mount Olympus: Los Angeles and the Production of the 1932 Olympic Mega-Event. Journal of Sport History. Volume 32, Number 2, 2005, pp. 137-165; e HENNIKER, Garth e JOBLING, Ian. Richard Coombes and the Olympic Movement in Australia : imperialism and nationalism in action. Sporting Traditions, vol. 6, n. 1, 1989, pp. 2-15.

${ }^{7}$ Cf. LEVERMORE, Roger and BUDD, Adrian (eds.). Sport and International Relations: an emerging reletionship. New York: Routledge, 2004.
} 
whether at the nation-state or the intra-state levels, and notions of identity and authenticity. (HILL, 2004, p. 2$)^{8}$

O historiador chama a atenção para os elementos que transcendem o esporte, "assuntos sérios” como o papel dos esportes na construção na nação e noções de identidade e autenticidade.

Discussões sobre a globalização, a importância de organizações internacionais nãogovernamentais na política, o efeito de movimentos transnacionais em relação à soberania e à relação entre os indivíduos e suas nações são assuntos da esfera dos estudos das Relações Internacionais e podem ser analisados a partir do ambiente dos esportes, principalmente nas grandes competições esportivas.

Segundo Aaron Beacom, há benefícios para as investigações em Relações Internacionais quando o foco da análise recai na organização do esporte. Tal análise oferece uma série de dados empíricos que podem auxiliar, ou contrariar, as recentes elaborações propostas para este campo. No caso das ações diplomáticas, por exemplo, o autor propõe que uma perspectiva mais pluralista contribuiria não só para um melhor entendimento da natureza da diplomacia relacionada ao esporte na sociedade contemporânea, mas também para investigar a diplomacia através da história dos esportes modernos (BEACOM, 2004, p. 96).

Por se tratar de uma pesquisa de História, procura-se estar atento às peculiaridades do método historiográfico e a uma construção mais segura de mecanismos que possam dar sustento à hipótese principal deste trabalho. A primeira atenção a tomar situa-se na natureza das fontes de informação do historiador, os documentos. Trabalha-se com a visão de que tal material é sempre mediato e foi registrado com determinada intenção por um grupo específico com objetivos estabelecidos. Outro ponto a se levar em conta é a perspectiva de temporalidade como inerente à pesquisa histórica, e que o "método historiográfico correto é o que entende que investigar e representar a História não é meramente descobrir coisas no passado cuja memória se havia perdido, mas dar conta de como as sociedades se comportam e evoluem no tempo” (ARÓSTEGUI, 2008, p. 95). Por último, parto também do princípio de

\footnotetext{
${ }^{8}$ Os trechos em inglês foram traduzidos por mim. As traduções aparecerão em nota de rodapé. "Uma vez que relações internacionais são, por definição, mais amplas que 'política internacional', elas automaticamente incorporam todas as atividades que envolvem dois ou mais países, mesmo aquelas de natureza meramente funcionais. No entanto, as questões mais interessantes sobre o esporte ou outras formas de associação civil são aquelas ligadas ao impacto que produzem nas coisas fora de seu campo de ação, o que dentro do [presente] contexto significa o caráter e a evolução do sistema internacional. [...] Longe dos clichês sobre os esportes, que incorporam rivalidades nacionais ou funcionam como válvula de escape para essas rivalidades, há algumas questões sérias a se pesquisar, como a do papel do esporte na construção da nação, quer no plano da naçãoestado quer no plano intra-estado, e as noções de identidade e autenticidade”.
} 
que o processo histórico é sempre global, pois agrupa a totalidade das atividades humanas, que por sua vez se interligam e se influenciam umas às outras.

Atento a estas peculiaridades, partiu-se para a coleta das fontes que pudessem dar, minimamente, conta dos objetivos principais deste trabalho: o de mostrar a forte relação entre as competições esportivas e a política externa brasileira a partir do uso dos eventos esportivos como ferramenta da política externa que solidifica os discursos relacionados ao gerenciamento das relações internacionais do país.

Para tanto, procedeu-se como recomenda Geoges Duby, e estabeleceu-se os limites desta investigação a partir das características da documentação encontrada (1993, p. 25). Procurou-se investir em fontes das mais variadas e por conta disso, propô-se uma classificação delas. Segundo Julio Aróstegui (2006, p.494),

a classificação das fontes tem interesse também, ao menos, pelo critério orientador que facilita a busca das fontes adequadas ao estudo de determinadas situações históricas, levando-se sempre em conta que o ideal de uma grande pesquisa é o uso das mais variadas fontes possíveis e a confrontação sistemática entre elas.

O material de trabalho constitui-se basicamente por três tipos de fontes. Uma vez que a hipótese recai sobre o intenso relacionamento entre o Estado, a sociedade e as competições esportivas, pesquisou-se fontes que pudessem ser analisadas e confrontadas com a problemática inicial proposta. No caso do Estado, partiu-se da análise de relatórios ministeriais, documentação legislativa e executiva publicada no Diário Oficial da República, além do recenseamento populacional de 1922.

A análise de periódicos da grande imprensa carioca e paulista trouxe pistas interessantes para se perceber como os jornais e revistas de maior circulação no país encaravam os eventos, e de que maneira criaram discursos relacionando as competições esportivas com aspectos da política externa brasileira. Porém, um olhar sobre alguns periódicos da imprensa estrangeira, no caso a norte-americana, também pode ajudar na comparação entre os discursos produzidos no país e os fora dele e clarear a compreensão da dimensão internacional dessas competições. Ademais, o relatório referente ao ano de 1922 do Fluminense Football Club (sede da maior parte das competições daqueles anos) e o recenseamento populacional, publicado no mesmo ano, serviram para confrontação de alguns dados provenientes dos periódicos e para uma melhor contextualização da situação populacional do país. 
As fontes utilizadas para este trabalho podem ser classificadas a partir de quatro critérios: o posicional, o intencional, o qualitativo e o quantitativo. Segundo o critério posicional, o conjunto dos documentos pode ser classificado como fontes diretas e indiretas. Trata-se com fontes diretas quando se tem registros feitos a partir daqueles que observaram diretamente os eventos, como os repórteres e, em alguns momentos, os próprios membros do governo quando estavam presentes às diversas atividades relacionadas às competições, não apenas jogos, mas também desfiles de abertura, recepções ou encontros com os membros das delegações estrangeiras. No entanto, algumas das fontes, às vezes provenientes dos mesmos meios, podem ser indiretas, ou seja, textos formulados a partir não da observação direta dos eventos, mas de informações obtidas indiretamente, como algumas crônicas e charges publicadas nos periódicos, a maioria das publicações oriundas dos periódicos internacionais.

Quanto à intencionalidade, trabalha-se com fontes consideradas testemunhais, ou voluntárias, ou seja, procedentes de um ato intencional de registro de dados, como o material proveniente dos periódicos (tanto as reportagens, como as crônicas e as charges), além dos relatórios ministeriais, do recenseamento de 1922 e do relatório do Fluminense.

Segundo o critério qualitativo, a maioria das fontes é de caráter cultural, não material, e narrativo. Devido a esta característica, segundo a classificação quantitativa, as fontes são de natureza não-serial, exceto os dados numéricos e econômicos que, mesmo assim, não são tratados aqui de maneira seriada (ARÓSTEGUI, 2006, pp. 492-503).

As fontes oriundas dos periódicos merecem um tratamento metodológico bastante cuidadoso. Deve-se estar alerta quando se trabalha com discursos que tentam representar determinadas percepções do social. No trabalho de discursos de autores da grande imprensa, torna-se necessário ter em mente que tais discursos são percepções que

não são de forma alguma discursos neutros: produzem estratégias e práticas (sociais, escolares, políticas) que tendem a impor uma autoridade a custa de outros, por elas menosprezados, a legitimar um projeto reformador ou a justificar, para os próprios indivíduos, as suas escolhas e condutas. (CHARTIER, 1990, p. 17)

Recorre-se, então, ao cuidado colocado por Gramsci, quando se lança um olhar sobre a produção jornalística. Segundo o autor, o jornalismo não pretende apenas "satisfazer todas as necessidades (de uma certa categoria) de seu público, mas pretende também criar e desenvolver estas necessidades e, consequentemente, em certo sentido, criar seu público e ampliar progressivamente sua área” (GRAMSCI, 1982, p. 161). O autor ainda chama a atenção para a maneira como os leitores devem ser abordados, colocando-os, ao mesmo 
tempo como elementos “ideológicos”, maleáveis à transformação, e “econômicos”, pois são agentes responsáveis por comprar as publicações e mantê-las no mercado.

A esses elementos, poderia ser adicionada a visão do leitor também como transformador, uma vez que as publicações podem criar e desenvolver necessidades, mas também como leitor ativo, influenciando também aquilo que é publicado.

Procede-se, então, à análise das duas primeiras grandes competições esportivas internacionais sediadas no Brasil, eventos que podem ser considerados marcos tanto no aspecto esportivo, quanto no estreitamento das relações entre essas competições e a política externa e a diplomacia brasileiras.

\section{9: “o congresso dos pés" 9}

O ano de 1919 foi bastante intenso em termos de política externa no Brasil. Para se ter uma ideia, um dos delegados brasileiros em Versalhes, ao participar das discussões que envolviam a formação da Liga das Nações e do tratado a ser imposto à Alemanha, foi o candidato à presidência do Brasil, Epitácio Pessoa. Enquanto a seleção brasileira de futebol disputava o torneio sul-americano e fazia a "diplomacia do pé”, o candidato esperava o resultado do pleito presidencial.

J. Carlos, um dos mais importantes ilustradores do país, deleitava os leitores com suas charges atentas ao momento particularmente estimulante, tanto na política, quanto nos esportes. Este ilustrador foi um dos que mais relacionou o campeonato com a política externa do país, além de se debruçar longamente sobre o papel exercido pelos torcedores, e, principalmente, pelas torcedoras durante a competição. J. Carlos publicava suas charges nas duas maiores revistas do país, a Careta e A Cigarra. Na Careta de 26 de abril de 1919, por exemplo, publicou uma em que Epitácio Pessoa, muito pequeno, está sentado no chão ao lado de uma mesa, maior do que ele. Epitácio, segura a toalha da mesa, torcendo-a, enquanto ao lado a legenda diz: “A torcida durante as eleições: como ficou o pano da mesa da Conferência de Versalhes”. O pano sendo torcido era uma alusão aos lenços e partes dos vestidos que as jovens moças presentes ao estádio torciam durante as partidas, e à “torcida” de Epitácio

\footnotetext{
${ }^{9}$ Este era o texto da legenda de uma ilustração de J. Carlos para a revista Careta, Rio de Janeiro, de 17 de maio de 1919, em que o autor colocava uma ilustração com duas mãos se cumprimentando, destacando que assim os líderes “inimigos” agiam na "Conferência de Paz”. Ao lado, outra ilustração com várias chuteiras, com a meia de cada pé com a bandeira de um país do torneio (Argentina, Brasil, Chile e Uruguai), uns em cima dos outros, colocando como os “amigos” se comportavam no "Congresso dos Pés”.
} 
quanto ao resultado das agitadas eleições presidenciais, na qual concorria contra o popular candidato Ruy Barbosa, em uma das eleições mais disputadas da Primeira República.

Na revista paulista A Cigarra, várias fotografias ilustram as páginas que têm, como texto, artigos de outra natureza. No entanto, na página em que aparecem as fotos das seleções do Brasil e do Uruguai, o texto é sobre a decisão da Liga das Nações em punir a Alemanha como culpada na Guerra. O autor chamava o Tratado de Versalhes de “Código de Ódio” e estampava que o Brasil e o Uruguai tinham acompanhado o voto dos outros membros da entidade. $^{10}$

A popularidade do torneio de futebol sul-americano foi tamanha, que até mesmo o The New York Times publicou uma nota em sua seção de esportes, com o título "Big crowd sees soccer", ${ }^{11}$ dando conta do jogo de estréia do Brasil na competição contra a seleção chilena, e destacou que 30 mil espectadores estavam no estádio, "including two thousand from other parts of South America [...]. The acting president [Delfim Moreira], members of the Cabinet and diplomats were present”. ${ }^{12}$ Um evento com o Presidente da República, membros do ministério, diplomatas, milhares de estrangeiros e duas representações nacionais em contenda, com arbitragem internacional de um representante de uma terceira nação (neste caso, o argentino Juan Pedro Barbera) não pode ser desconsiderado como um evento de relações internacionais. Muitos dos que viveram o período pensavam dessa maneira. Pelo menos é o que transparece no discurso dos grandes periódicos da época.

Outro jornal norte-americano, o texano The Corpus Christy Caller, reconhecia o futebol como o principal esporte dos brasileiros. Comparava a popularidade do baseball nos Estados Unidos com a do futebol no Brasil, e dava conta do crescimento da organização de campeonatos municipais, estaduais e nacionais para a escolha do "all star team [...] to represent Brazil in annual series for the championship of America”. ${ }^{13}$ Chamava ainda a atenção para o fato de o Fluminense ter 3.000 sócios $^{14}$ e ter construído um estádio de "half

\footnotetext{
${ }^{10}$ ZEMA. “A Caveira e o Alfarrabio”. A Cigarra, São Paulo, ano VI, n. 113, 1 jun., 1919, pp. 22 e 23.

11 “Grande multidão acompanha o futebol”.

12 “incluindo dois mil espectadores de outras partes da América do Sul [...] O presidente em exercício, membros do governo e diplomatas estavam presentes”. BIG crowd sees soccer. The New York Times, Nova Iorque, 13 mai. 1919. Disponível em: <http:/query.nytimes.com/mem/archive-free/pdf?res=990CE4DC163AE03ABC4B52DFB3668382609EDE>. Acesso: 13 mar. 2011.

13 "time de estrelas para representar o Brasil no campeonato anual sul-americano".

${ }^{14} \mathrm{O}$ clube tinha, na verdade, 2.500 sócios. Cf. FLUMINENSE FOOTBALL CLUB. Relatório dos Trabalhos Sociais concernentes ao anno de 1919. Rio de Janeiro: Papelaria Macedo, 1920.
} 
million dollars [...] with a seating capacity of 30.000”. ${ }^{15}$ O pequeno jormal The Evening Missourian colocava que, finalmente, o Brasil tinha bons atletas e que o que mais deveria ser notado no evento não era a vitória da seleção brasileira, mas sim "the great interest taken in the sports by the people of all ages", ${ }^{16}$ destacando mais à frente que o estádio, com capacidade para 40 mil pessoas, ficava lotado, e restava aos espectadores assistir as partidas em um morro ao lado: “A hill overlooking the playing field was black with people”. ${ }^{17}$

O Brasil foi o campeão do torneio. À parte da violência dos jogos, segundo reportagens da grande imprensa, o evento não trouxe maiores problemas entre as nações. $\mathrm{O}$ torneio teve duas partidas finais, entre a seleção brasileira e a uruguaia, esta última defendendo seu título de bi-campeã da competição, em 1916 e 1917. Após um empate no jogo da final, nova partida foi marcada entre as seleções para o desempate. A competição tinha quatro árbitros, os brasileiros Adilton Ponteado e Joaquim de Castro, o inglês Robert Todd, que apitou a primeira final, e o argentino Juan P. Barbera, escalado para arbitrar a segunda final.

O jogo acabou em zero a zero. Foi então disputada uma prorrogação, com dois tempos de 15 minutos a mais para se jogar. Se houvesse mais um empate na prorrogação, nova partida deveria ser marcada. Isso atrasaria ainda mais a competição, elevaria os custos de hospedagem e alimentação dos atletas e da comissão técnica uruguaia, além das hospedagens dos jogadores dos clubes paulistas que se encontravam no Rio de Janeiro para defender a seleção brasileira, ao lado dos jogadores dos clubes cariocas. Ademais, como a CBD exigia que os atletas fossem amadores, os jogadores paulistas, e provavelmente os cariocas também, recebiam quantias em dinheiro da CBD como "ordenados" por deixarem seus empregos e se dedicarem aos treinamentos e jogos em tempo integral, além de outras ajudas de custo para transporte, por exemplo. Mais uma partida significa mais custos para a CBD. ${ }^{18}$

O primeiro tempo da prorrogação acabou sem gols e os 15 minutos do segundo tempo também. O árbitro argentino não terminou a partida. A seleção brasileira atacava

\footnotetext{
15 “meio milhão de dólares [...] com capacidade para 30.000 pessoas”. “Football Popular Sport in Brazil”. The Corpus Christi Caller, 6 de julho de 1919, p. 18. Disponível em: http://chroniclingamerica.loc.gov/lccn/sn86071134/1919-07-06/ed-1/seq-18/.

16 “o grande interesse nos esportes por pessoas de todas as idades”.

17 “Uma montanha ao lado do estádio com vista para o campo estava negra com pessoas”. HAAS, Lawrence S. “Brazil Now Has Good Athletes”. The Evening Missourian, n. 267, 12 de julho de 1919, p. 4. Disponível em: <http://chroniclingamerica.loc.gov/lccn/sn89066315/1919-07-12/ed-1/seq4/;words=Brazil+football?date1=1919\&sort=date\&date2=1922\&searchType=basic\&state=\&rows=20\&proxtext $=$ Brazil + football $\& y=0 \& x=0 \&$ dateFilterType $=$ yearRange\&index $=6>$. A revista Careta publicou as fotos do morro tomado por pessoas. Cf. Careta, Rio de Janeiro, anno XII, n. 571, 31 mai. 1919, pp. 23.

${ }^{18}$ Sobre o pagamento de dinheiro aos atletas amadores da seleção por parte da CBD, Cf. Santos (2010, pp.169$180)$.
} 
constantemente, e o gol poderia sair a qualquer momento. Já com dois minutos além do tempo regulamentar, os jogadores brasileiros fizeram mais um ataque e o atacante paulista Friedenreich assinalou o gol da vitória do Brasil.

Inúmeras fotos foram publicadas nos principais periódicos paulistas e cariocas para celebrar o feito da seleção brasileira. Nas grandes revistas dessas capitais, ilustradores, como Seth e J. Carlos, usaram a vitória como objeto de críticas e humor. J. Carlos tinha sido um dos mais atentos à participação dos torcedores e, principalmente, das torcedoras no estádio durante a competição. Fez inúmeras ilustrações das jovens moças se contorcendo e torcendo seus lenços e vestidos, roendo as unhas ou celebrando as vitórias, carregando jogadores no colo, com bandeiras do Brasil. Para ironizar a atuação do argentino Barbera na arbitragem do jogo final e a suposta ajuda ao selecionado nacional, J. Carlos publicou uma caricatura do árbitro na revista carioca Careta, em meia página, com seu rosto por inteiro, sorrindo, e sendo celebrado por duas torcedoras. ${ }^{19} \mathrm{O}$ "referee” era mostrado como se fosse mais um jogador da seleção brasileira. As relações entre Brasil e Argentina eram assim comemoradas, de maneira irônica, apontando o auxílio do representante da nação vizinha no sucesso do Brasil.

No entanto, o campeonato de 1919 que acabava em festa para os brasileiros teve uma nota bastante triste, principalmente para os uruguaios, além da derrota no campo. Durante o campeonato, o jovem goleiro reserva da seleção uruguaia, Robert Chery, participou do segundo jogo contra a equipe chilena. Após uma defesa, rompeu uma hérnia e foi internado no hospital, vindo a falecer duas semanas depois, justamente no dia da segunda final entre Brasil e Uruguai. Sua morte, anunciada momentos depois da vitória brasileira, mereceu o editorial da revista A Cigarra. O texto é riquíssimo. Cita-se, portanto, algumas das passagens mais significativas. O autor inicia afirmando que as comemorações tiveram uma nota triste:

Justamente no momento em que o grande pleito se decidia, quando acalmava a ansiedade tempestuosa e oppresora e torturante de quarenta milhões de almas; quando as bandeiras de quatro nações tremulavam ovantes ao lindo sol outomniço da bahia da Guanabara; [...] quando, enfim, a glória sorria á nossa pátria, uma victória tão cubiçada, e se estendiam em irradiações de amizade, por todos os povos do continente - a Morte descia, cruel e implacavel, ceifando uma vida. ${ }^{20}$

Nesta primeira parte, o editorial já demonstra uma série de aspectos importantes com os quais se lida neste artigo. O primeiro deles é quando o autor transporta para toda a

\footnotetext{
${ }^{19}$ BARBERA. J. Carlos. Careta, Rio de Janeiro, ano XII, n. 572, 7 jun. 1919, p. 22.

${ }^{20}$ As notas a seguir são do editorial CHRONICA da revista A Cigarra, São Paulo, ano VI, n. 115, 14 jun. 1919 , p. 15.
} 
população de aproximadamente quarenta milhões de habitantes que o país teria, na época, os anseios de alguns milhares de espectadores que acompanhavam o jogo. ${ }^{21}$ São os discursos das nações imaginadas, que Benedict Anderson tão habilmente descreveu e problematizou. Nações que se materializam em símbolos, como nas bandeiras tremulantes no estádio, e estabelecem as celebrações que irradiam amizade por todas as partes do continente, ou na glória que sorria à pátria após a cobiçada vitória. O editorial continuava com a descrição do funeral daquele "moço de 20 annos, que era um humilde”, mas que havia se convertido em “celebridade” após a sua morte:

Velaram o seu corpo não só os seus leaes amigos e companheiros de muitas batalhas, mas também altos representantes de delegações esportivas, diplomatas, jornalistas, escriptores, a melhor sociedade da capital brasileira. [...] Pensou-se na sua família. Resolveu-se sobre o transporte de seus despojos mortaes para a sua terra natal. Em summa, prestaram-se-lhe todas as homenagens que só costumam tributar-se aos grandes homens. Uma consagração como somente merecem os herois.

Tamanha honraria para um jogador de futebol? Ainda um reserva? Que forças estariam em jogo em uma competição e na morte de um jogador que fizeram com que seu funeral fosse rodeado de figuras proeminentes, inclusive da política internacional? Como um jogador estrangeiro conseguia tais honrarias, a ponto de ter seu corpo enviado para sepultamento do Rio de Janeiro para o Uruguai e envolvendo ações diplomáticas entre os dois países ${ }^{22}$ Se a proposta é analisar os esportes como veículo para ações diplomáticas, como sugerido por Houlihan (op. cit.), tem-se, nesse fato, um excelente exemplo desse tipo de ação. Seria essa também a proposta colocada por Beacom de uma perspectiva mais pluralista das ações diplomáticas e de uma investigação dessas ações através da história dos esportes modernos (op.cit.).

Não desprezando essas forças, pode-se ver como a morte do jovem goleiro em solo brasileiro levou os governos dos dois países a uma ação diplomática no momento em que as duas nações disputavam a liderança nas questões desta parte do continente no Conselho da Liga das Nações. Os esportes transformavam-se em palco para as ações de aproximação ou distanciamento dos países. As competições internacionais não eram apenas jogos que

\footnotetext{
${ }^{21}$ Segundo o censo realizado em 1920, o país tinha 30.553.509 habitantes. Cf. BRASIL. Recenseamento do Brasil realizado em $1^{\circ}$ de setembro de 1920. Rio de Janeiro: Typographia da Estatística, 1922.

${ }^{22} \mathrm{O}$ corpo do jogador foi velado na Casa de Saúde Pedro Ernesto e depois conduzido à sua terra natal, onde foi sepultado. De acordo com a revista carioca Fon-Fon, “a Confederação Brasileira de Desportos fez embalsamar o corpo e transportal-o para Montevideo”. Após a morte do atleta, foi organizada a disputa entre as seleções do Brasil e Argentina em homenagem ao jovem jogador uruguaio, a Taça Robert Chery. O CERTAMEN Sportivo Sul Americano. Fon-Fon, Rio de Janeiro, ano XIII, n. 23, 7 jun., 1919, pp. 38 e 39.
} 
envolviam atletas representando suas nações, envolviam forças sociais, política externa e diplomacia. Não podem mais ser analisadas, senão dentro de um escopo de um conjunto de ações e atividades que fazem parte da esfera das relações internacionais.

Na continuação do editorial, o autor faz de Robert Chery um verdadeiro mito: "morreu como um herói”. O arqueiro "tombou para defender a honra de sua bandeira e o nome de sua terra”. Ao comparar Chery com os "moços que na última guerra enfrentaram a morte com o sorriso nos lábios” o editorial colocava que uns e outros “obedeciam ao mesmo ideal de grandeza nobilitante" com a diferença que, no caso das guerras, "se derramava o sangue, explodiam as paixões e semeava-se o ódio”. Defendia que nos campos esportivos, “uniam-se povos irmãos, em pugnas pacíficas, por vínculos de uma fraternidade mais ampla, mais verdadeira e mais integral”. Por isso, argumentava serem os atletas "os heroies simples da Belleza espiritual e da Belleza physica, os campeões de uma raça mais perfeita e de um mundo melhor, no qual todas as almas se estreitam num amplexo de fraternidade verdadeira e sincera”.

Na sequência, continuam as caracterizações do arqueiro como um herói, sem deixar de lado a visão das competições internacionais e os atletas que representavam seus países como os principais expoentes de uma nova ordem pacífica assente em princípios estabelecidos em um passado distante:

E foi assim que Robert Chery morreu para defender um 'goal', como o vigia que se deixa matar ás portas de uma fortaleza. O rectangulo da rede é a poterna da cidadella da honra e da gloria aonde pelejam os cavaleiros da nova Távola Redonda, [...] Se tivesse estado nas Termoplytas seria dos trezentos invencíveis de Leonidas; se tivesse partido para a guerra, seria um dos gloriosos vencedores [...] um dos soldados da victória. Assim, foi simplesmente um herói do sport.

Para se entender essa passagem, pode-se recorrer a Hobsbawn (2002, pp. 09-17) quando expõe as tradições inventadas, ou a necessidade das sociedades constituídas a partir da Revolução Industrial de estabelecer vínculos com novas situações (no caso, as competições esportivas internacionais) e certos aspectos de um passado selecionado, na tentativa de legitimação de instituições e simbolização de coesão social. Os cavaleiros medievais e os temíveis espartanos da Antiguidade Clássica são recuperados na rememoração de um herói de novo tipo, de uma nova ordem, um herói dos esportes.

Após 1919, o governo sentia-se apto a dar um passo ainda maior em relação aos esportes como veículo de projeção internacional do país. Os Jogos Olímpicos SulAmericanos, realizados em 1922, como parte dos festejos dos cem anos de independência do 
Brasil, foram uma etapa decisiva na consolidação do Brasil na rota dos grandes eventos esportivos mundiais.

\section{2: “Sympathias e relações não se fazem a pontapés. Sobretudo, quando os pés não tomaram chá em pequenos...". ${ }^{23}$}

O evento de 1919 mostrou para as autoridades brasileiras que as competições esportivas haviam alcançado um relevante status, tanto nas questões internas, quanto nas externas. A união dos países em uma competição de futebol regional, a vitória dos brasileiros, as possibilidades de homenagens e ações relacionadas a figuras importantes da diplomacia apresentavam-se como excelentes oportunidades para acrescentar ingredientes às ações do governo.

O ano de 1922 marcava uma data de bastante relevância para a história do Brasil. O país comemorava o centenário de sua independência em meio a um clima político conturbado, com eleições presidenciais acaloradas e revoltas militares. ${ }^{24}$ Várias ações foram planejadas para dar conta dos festejos de maneira a projetar uma nova ideia de modernidade para o país, tanto no quadro internacional, quanto no nacional. Neste ponto, o número de ações dos gestores do Estado que visavam estabelecer mecanismos que trouxessem a ideia de pertencimento à nação, à “comunidade imaginada” de Benedict Anderson, foram ainda mais numerosas e relevantes, principalmente no uso dos esportes e das competições esportivas internacionais como instrumentos de produção desse discurso.

Ainda em 1919, durante o Congresso da Confederação Sul-Americana de Futebol, realizado em meio à disputa do torneio internacional de futebol no Rio de Janeiro, os dirigentes esportivos brasileiros conseguiram fazer da Capital Federal novamente a sede da disputa da competição no ano do centenário. Com um plano bem mais ousado e com apoio do governo, da Associação Cristã de Moços (através da ação de seu representante internacional, o norte-americano Elwood Brown), ${ }^{25}$ e do próprio COI, a CBD tratou de organizar uma

\footnotetext{
${ }^{23}$ Revista Para Todos, Rio de Janeiro, ano IV, n. 199, 7 out. 1922, p. 18.

${ }^{24}$ O Brasil passava por períodos conturbados na política, principalmente nas Forças Armadas, com o levante do Forte de Copacabana, nas eleições presidenciais entre Artur Bernardes e Nilo Peçanha, no debate do Senado pela censura na imprensa, pela formação do Partido Comunista do Brasil. Para melhor entender o contexto político do período, entre outros, Cf. SOUZA (1979) e FERREIRA (1993).

${ }^{25}$ Elwood Brown era também secretário do Comitê Olímpico Internacional e grande entusiasta dos jogos regionais entre nações, como os Jogos de 1922, primeiro a ser realizado no mundo. Naquele mesmo ano, Brown tentou a organização de jogos em outras regiões, porém sem sucesso. O norte-americano foi também o idealizador dos primeiros jogos mundiais militares, conhecidos como "Inter-Allied Games”, realizados em 1919. Cf. BUCHANAM (1998).
} 
competição sul-americana poliesportiva nos moldes dos Jogos Olímpicos, algo inédito tanto no continente, quanto no mundo.

A aprovação do COI se deu em 1920, durante seu $18^{\circ}$ encontro anual, realizado em Antuérpia, na Bélgica. A competição ficou conhecida como “The South American Olympic Games”, uma espécie de “Olimpíada intermediária”, entre os Jogos Olímpicos de Antuérpia, em 1920, e de Paris, em $1924 .{ }^{26}$ Ainda em dezembro de 1919, através da publicação de um decreto-lei, o governo já havia autorizado o Fluminense a realizar uma operação de crédito para que o clube pudesse obter os fundos necessários para a realização das obras de ampliação e melhora nas instalações esportivas na sede do clube, visando receber a importante competição. $^{27}$

A organização dos Jogos de 1922 foi minuciosamente articulada com o governo. O coronel do exército brasileiro, Estellita Werner, foi nomeado presidente da Comissão Organizadora dos Festejos Desportivos do Centenário para, ao lado da CBD, promover o evento, que constava como atividade oficial do "Programma para as commemorações do Centenário da Independência”. Tal programa, publicado no Diário Oficial por parte do Ministério da Justiça e dos Negócios Exteriores, tinha 22 atividades. A Exposição Universal aparecia encabeçando a lista, que tinha os Jogos de 1922, como a $16^{\mathrm{a}}$ atividade do programa: “Celebração dos jogos olympicos devendo ser promovida a representação, nos mesmos, de todas as formas e todos os nucleos principaes do sport nacional”. ${ }^{28}$

O Cel. Werner criou uma comissão especial para homenagear “as altas autoridades do paiz e bem assim as representações diplomáticas e desportivas que [nos honravam] com suas presenças”. Tratava-se da “Comissão de Diplomacia”, formada por figuras de destaque como o escritor e apaixonado torcedor do Fluminense, Henrique Maximiliano Coelho Netto. ${ }^{29}$ Tal iniciativa mostra claramente que os agentes do governo encaravam as relações internacionais de uma maneira pluralista, tomando-a como ferramenta para ações diplomáticas.

O momento da política internacional apresentava-se de maneira bastante delicada. Após o término dos conflitos da Primeira Grande Guerra, o Brasil teve, sob a tutela dos Estados Unidos, atuação destacada na formação da Liga das Nações. Apesar de não conseguir

\footnotetext{
${ }^{26}$ BRAZIL to hold the Games: Intermediate Olympics awarded to South America for 1922. The New York Times, Nova Iorque, 25 ago., 1920. Disponível em: <http://query.nytimes.com/mem/archivefree/pdf?res=940CE2D91F31E03ABC4D51DFBE66838B639EDE>. Acesso: 15 mar. 2011.

${ }^{27}$ Para conferir como funcionava a operação financeira Cf. BRASIL. Decreto n. 3.955. Diário Official dos Estados Unidos do Brasil, 31 de dezembro de 1919, p. 19.350.

${ }^{28}$ BRASIL. Diário Oficial. Ministério da Justiça e dos Negócios Interiores. "Programma para a commemoração do Centenário da Independência”. 4 de fevereiro de 1921, p.2.538.

${ }^{29}$ A CREAÇÃO da Comissão de Diplomacia dos Festejos Desportivos do Centenário. O Imparcial, Rio de Janeiro, 6 set. 1922, p. 3.
} 
um assento permanente no Conselho Executivo da entidade supranacional, o Brasil foi nomeado para um dos cinco postos temporários, com mandato de três anos (BURNS, 1977, p. 400). Por intermédio de uma intensa atuação do presidente Epitácio Pessoa e do representante do Brasil no Conselho em Genebra, Afrânio de Melo Franco, o país não só objetivava uma cadeira permanente, como tinha que manter sua posição como membro temporário do Conselho, uma vez que apenas o primeiro mandato fora obtido por nomeação dos membros da Liga. A $3^{\text {a }}$ Assembléia do Conselho da Liga das Nações realizar-se-ia em outubro de 1922 (ELLIS, 2004, pp. 139 e 140). Como notam Cervo e Bueno, “o Brasil, em nome da América, lançou a sua candidatura. A questão toda colocava-se em termos de prestígio" (CERVO e BUENO, 2010, p. 223).

O Centenário, a Exposição, as reformas e inaugurações, as paradas militares, os desfiles, os jogos, todos os eventos apresentavam-se como oportunidades ímpares para a criação de situações múltiplas visando ao estreitamento das relações com as autoridades internacionais presentes no país, os indivíduos que realmente faziam o jogo da política internacional. Os "Jogos Olympicos Latino Americanos”, 30 além de terem a função de lazer para os cariocas e para muitos brasileiros e estrangeiros que acompanhavam as festividades do Centenário da Independência, ${ }^{31}$ serviram para ser mais um dos muitos eventos desta natureza.

Estados Unidos, Japão, França, Grã-Bretanha, e Itália, membros permanentes do Conselho, não só estavam representados na Exposição, como tinham seus pavilhões construídos um ao lado do outro, logo na entrada do evento, após o pavilhão da Argentina, o primeiro prédio do complexo construído especificamente para este evento. Dos membros temporários, Bélgica e Suécia também se fizeram representar, enquanto China, Espanha e Uruguai não participaram da Exposição com pavilhões. Os uruguaios, no entanto, tiveram forte presença nos esportes, inclusive com a temida seleção de futebol. Algumas das mais importantes autoridades daquele país faziam parte da chamada "Embaixada Uruguaia”, como o Sub-Secretario de Estado das Relações Exteriores, Alvaro Savalegui. ${ }^{32}$

Os eventos da celebração do Centenário renderam uma grande reportagem de quase meia página no jornal norte-americano The New York Times, com o título “Our part in

\footnotetext{
${ }^{30}$ BRASIL. Diário Official, 3 de março de 1921, p. 4.312.

31 Muitos estrangeiros vieram em excursões turísticas, como os argentinos, que pagavam 1.000 pesos, ou 2:660\$000, por uma viagem de 30 dias ao Rio de Janeiro (O Imparcial, Rio de Janeiro, $1^{\circ}$ ago. 1922 , p. 10. CÂMBIO. Jornal do Commercio, 2 jan., 1922, p.13), ou os americanos, vindos em vapores alugados pela "firma de touristas Thomas Cook \& Sons” que ficaram 15 dias no Rio de Janeiro (TEREMOS pelo Centenário a visita de touristes americanos. O Imparcial, Rio de Janeiro, 15 ago. 1922, p. 3).

${ }^{32}$ SPORTS. O Imparcial, Rio de Janeiro, 24 ago. 1922, p. 3.
} 
Brazil’s big show”. ${ }^{33} \mathrm{O}$ autor do artigo destaca que a exposição seria o maior evento deste tipo que já havia ocorrido na América do Sul e colocava que, quando o secretário de Estado norte-americano Charles Hugues chegasse ao Brasil para a inauguração do evento, seria o terceiro norte-americano neste posto a visitar a América do Sul. Para o autor, "the exposition is of particular interest of America because it enphasizes the enterprise of the southern neighbor”. Ao finalizar o texto, o autor diz que

The exposition has been planned as an expression of the economic and social progress of Brazil during the last century. Exhibits will include agriculture, cattle raising, industries and commerce, general and social economics, education, transportation and communication, public service, history and geography, sports, military science and fine arts. There will be [...] Olympic Games, for wich leading athletes have been entered from this country and Europe. The games will be the first of the sort held in South America on anything like a world scale and are of particular interest as furnishing a line on what may be expected from Latin American athletes of the contest on the last Olympic Program. ${ }^{34}$

No contexto de aproximação dos dois países, o presidente dos Estados Unidos, Warren Harding, não esteve presente aos festejos do centenário, porém, enviou uma "special mission of friendship, goodwill and congratulation to represent the Government and the people of United States”, chefiada pelo secretário de Estado Charles Evan Hugues. O presidente Harding enviou um comunicado ao "great and good friend”, presidente Epitácio Pessoa, elevando Hugues ao posto de “Ambassador Extraordinary and Plenipontenciary”, em retribuição à visita que D. Pedro II havia feito aos Estados Unidos em ocasião do centenário da Independência daquele país, em $1876 .{ }^{35} \mathrm{E}$ o presidente Epitácio Pessoa, em seus momentos finais na presidência, respondeu ao "grande e bom amigo”, presidente Harding,

\footnotetext{
33 "Nossa parte no grande 'show' do Brasil”.

34 A exposição foi planejada para expressar o progresso econômico e social do Brasil no último século. São exibições de agricultura, criação de gado, indústrias e comércios, economia social e geral, educação, transporte e comunicação, serviços públicos, história e geografia, esportes, artes militares e belas artes. Haverá [...] Jogos Olímpicos, para os quais foram admitidos os melhores atletas deste país e da Europa. Esses jogos serão os primeiros deste tipo a ter lugar na América do Sul, em escala mundial, e são especialmente interessantes para mostrar o que se deve esperar dos atletas sul americanos presentes no final do Programa Olímpico. OUR Part in Brazil's big show. The New York Times. Nova Iorque, 27 ago. 1922. Disponível em: $<$ http://query.nytimes.com/mem/archivefree/pdf?res=F30A1FF73B5D14738DDDAE0A94D0405B828EF1D3>. Acesso em: 13 mar. 2011.

${ }^{35}$ BRASIL. "Relatório do Ministério das Relações Exteriores de 1922 e 1923: III- Credencial do Sr. Charles Evans Hugues na qualidade de Embaixador Extraordinário e Plenipotenciário”. Anexo A, n. 48. Rio de Janeiro: Imprensa Nacional, p. 55.
} 
estar "muito penhorado por esta prova de apreço", e ter dado "o mais amistoso acolhimento" ao secretário Hugues. ${ }^{36}$

Em seu discurso na inauguração da Exposição, o secretário fez questão de deixar claro que havia a necessidade de uma maior colaboração entre os dois países. Suas palavras mostravam que a aproximação dos países americanos na política internacional estava em pleno funcionamento.

The people of United States and Brazil are alike devoted to the ideals of peace. We of this hemisphere are happy to be free from any menace of aggression. Many of the most important controversies have been solved or are in process of solution. Why should we not have an enduring peace and benefits of co-operation? ${ }^{37}$

Através desse tipo de discurso, percebe-se a aproximação dos governos de Brasil e Estados Unidos e o destaque dos ideais de paz como a tônica do comportamento mais geral dos dois países. Assim, o governo brasileiro estreitava seu alinhamento com o novo eixo de poder constituído no mundo pós-guerra, e deslocava a dependência da Europa (exceto algumas dependências econômicas com Londres) para os Estados Unidos, um dos pontos fundamentais das relações internacionais do país durante a Primeira República (CERVO, op.cit., p. 43).

Nos esportes, as delegações argentina, brasileira, chilena, paraguaia e uruguaia disputavam os Jogos Sul-Americanos. Mas, junto dos Jogos, foram disputados os Jogos Mundiais Militares, que contaram também com delegações das Forças Armadas destes países sul-americanos e dos Estados Unidos, Bélgica, Japão e Reino Unido.

Os jogos começaram alguns dias após a inauguração da Exposição. No dia 13 de setembro, no estádio do Fluminense, houve um desfile de algumas das delegações que participavam na competição, tanto nos “Jogos Olympicos”, como nos Jogos Militares. Estavam representadas as delegações desportivas da Argentina, do Brasil, do Chile, dos Estados Unidos, da Grã-Bretanha, do Japão, do Paraguai e do Uruguai. Segundo o relatório do Ministério do Exterior para o ano de 1922, as “Delegações Desportivas Estrangeiras” tiveram

\footnotetext{
${ }^{36}$ BRASIL. "Relatório do Ministério das Relações Exteriores de 1922 e 1923: IV- Resposta à Carta-Credencial do Senhor Charles E. Hugues. Anexo A, n.49. Rio de Janeiro: Imprensa Nacional, p. 56.

${ }^{37}$ HUGUES Proclaims Pan-American Aims. The New York Times. Nova Iorque, 9 set., 1922. Disponivel em: $<$ http://query.nytimes.com/mem/archive-free/pdf?res=F20713F93B5D1A7A93CBA91782D85F468285F9>.

Acesso em: 13 mar. 1922. Discurso do secretário de Estado norte-americano, Charles E. Hugues, durante a Exposição de 1922 no pavilhão dos Estados Unidos para residentes norte-americanos no Brasil.
} 
destaque para "além dos jogos olympicos, a que concorreram delegações desportivas de alguns paizes amigos” ao participarem da "grande parada desportiva”. 38

O desfile das delegações esportivas teve ampla cobertura da grande imprensa carioca. As principais revistas apresentaram inúmeras fotos em seu interior. A Careta publicou um pôster de duas páginas com quatro fotografias do evento, a maior delas uma panorâmica com todas as delegações perfiladas de frente para as cadeiras numeradas. Ao fundo, pode-se observar as arquibancadas e as gerais do estádio completamente vazias, o que revela o desinteresse do público em geral pelo desfile. ${ }^{39}$ Já na revista $O$ Malho, foi publicada uma página inteira, com oito fotos das delegações presentes à "parada sportiva internacional”. ${ }^{40} \mathrm{~A}$ Fon-Fon!, outra revista de grande circulação, foi a que deu maior destaque à parada esportiva, distribuindo nove fotografias por seis páginas da edição de 23 de setembro. ${ }^{41}$ Até mesmo a revista Para Todos, especializada em cinema e teatro, deu destaque à parada esportiva. As mesmas oito fotografias publicadas na revista $O$ Malho em uma página, foram divididas em duas páginas na Para Todos. ${ }^{42}$

Com o desenrolar da competição, principalmente o campeonato de futebol, os periódicos passaram a dar destaque para a violência dos jogadores durante os jogos. A partida disputada entre os uruguaios e argentinos foi uma das que receberam destaque negativo por conta do comportamento dos atletas. Ao final do segundo tempo, perdendo por um a zero, os jogadores argentinos, segundo o autor do texto do jornal paulista Folha da Noite, passaram a usar de violência desmedida, inclusive com um dos jogadores aplicando uma "bofetada” em seu adversário uruguaio. ${ }^{43}$

A revista Para Todos condenava a atitude dos jogadores no torneio e imputava à provável origem mais humilde dos atletas a causa para um comportamento longe de ser diplomático:

O Campeonato Sul-Americano de Foot-Ball, inventado para estreitar as relações e unir as sympathias dos vários paízes deste pedaço do mundo, falhou definitivamente. Sympathias e relações não se fazem a pontapés. Sobretudo, quando os pés não tomaram chá em pequenos.... ${ }^{44}$

\footnotetext{
${ }^{38}$ BRASIL. "Relatório apresentado ao Presidente da Republica dos Estados Unidos do Brasil pelo Ministro das Relações Exteriores”. Rio de Janeiro: Imprensa Nacional, 1924, p. 8.

${ }^{39}$ A PARADA Sportiva. Careta, Rio de Janeiro, ano XV, n. 744, 23 set. 1922, pp. 30 e 31.

${ }^{40}$ A PARADA Sportiva Internacional. O Malho, Rio de Janeiro, ano XXII, n. 1.045, 23 set., 1922, p. 75.

${ }^{41}$ Fon-Fon!, ano XVI, n. 38, 23 de setembro de 1922, pp. 12, 14, 16, 18, 20 e 22.

${ }^{4}$ No STADIUM do Fluminense. Revista Para Todos, Rio de Janeiro, ano IV, n. 197, 23 set., 1922, pp. 26 e 27.

${ }^{43}$ O SUL-AMERICANO. Folha da Noite, São Paulo, 8 out., 1922, p. 5.

${ }^{44}$ Revista Para Todos, Rio de Janeiro, Ano IV, n. 199, 7 out., 1922, p. 18.
} 
O artigo terminava com a seguinte conclusão: “Um pouco lamentável o espetáculo de alguns seleccionados, muito mal seleccionados...”. 45 Mesmo criticando o comportamento dos jogadores, a crônica destaca o objetivo da competição "estreitar as relações e unir as sympathias dos vários paízes deste pedaço do mundo”. Mas o projeto falhava por conta da origem humilde dos jogadores, incapazes de se comportar civilizadamente, e revelava, também, um discurso que direcionava os problemas advindos da competição, não ao projeto, mas à condição social dos jogadores de futebol.

Porém, o pior “acidente diplomático” ainda estava por vir. Aconteceu no campo do Fluminense, durante o jogo decisivo entre as seleções do Uruguai e do Paraguai. O provável causador do incidente? O árbitro brasileiro que, segundo parte da grande imprensa do período e dos jogadores, técnicos e dirigentes uruguaios, favoreceu a seleção paraguaia para que os brasileiros não fossem eliminados da competição.

Para entender o problema, torna-se necessário entender a situação em que se encontravam as seleções na competição. A seleção brasileira estava praticamente eliminada da competição e o jogo referido seria a última chance da seleção do Brasil continuar e se sagrar campeão do torneio. Faltavam ainda três jogos a ser realizados. Primeiro, o jogo entre as seleções do Paraguai e do Uruguai. A seleção uruguaia precisava apenas de um empate para sagrar-se campeã. Já a seleção paraguaia precisava vencer a partida para empatar em número de pontos com os uruguaios. A partida seguinte seria entre Brasil e Argentina. O Brasil só poderia ter chance na competição em caso de vitória dos paraguaios no jogo contra os uruguaios e com a posterior vitória contra os argentinos. Com esses resultados, o Brasil empataria em pontos com Uruguai e Paraguai. A última das partidas ainda tinha implicações para o futuro da seleção brasileira na competição. A já eliminada seleção argentina precisaria derrotar o Paraguai, forçando partidas extras entre essas seleções para a decisão do campeão. Ou seja, o título estava praticamente decidido entre as seleções do Uruguai e do Paraguai, que dependiam apenas de seus resultados.

Se na política externa o Brasil atuava sob o paradigma da cordialidade oficial, "um padrão de conduta que assenta na percepção da grandeza nacional que por si só torna supérfluos sentimentos de rivalidade ou hostilidade por parte dos dirigentes brasileiros" (CERVO, 2008, p. 205), tão presente nas ações das comemorações do Centenário, no futebol o paradigma foi o da rivalidade. A Comissão Organizadora não escalou um árbitro neutro para a partida entre uruguaios e paraguaios. Colocou um brasileiro, Carlos Santos,

\footnotetext{
${ }^{45}$ Idem.
} 
representante de uma seleção diretamente interessada no resultado. Independentemente de ter ou não acertado em anular dois gols da seleção uruguaia, qualquer tipo de marcação duvidosa contra os uruguaios levantaria suspeitas. Após o segundo tento anulado, o árbitro brasileiro foi rodeado pelos jogadores uruguaios, que tentavam agredi-lo. Dirigentes e técnicos entraram em campo, juntamente com a polícia, e a confusão foi estabelecida. Os jogadores se recusaram a continuar a partida, abandonaram a competição e retornaram a Montevidéu dias depois.

Os ilustradores das revistas se deliciavam em torno das polêmicas. A verdadeira obsessão em vincular o esporte à prática diplomática e à violência praticada no campo de futebol por parte das seleções foi, reiteradas vezes, objeto de sátiras nas charges e caricaturas de ilustradores como Belmonte, Seth, e J. Carlos.

Este último estava sempre atento ao envolvimento do futebol com a sociedade e a política. Foram muitas as charges e caricaturas publicadas por J. Carlos para as revistas cariocas Careta e O Malho, além da paulista A Cigarra, em que o autor relacionava o futebol com as relações internacionais do país. Devido ao limite do trabalho, apresentou-se apenas duas delas. Em uma das mais significativas, o autor ilustrou a capa da edição de 30 de setembro de 1922, quando a competição de futebol já tinha duas semanas e muitas polêmicas. Colocou dois diplomatas em trajes de gala diferentes disputando uma partida de "ping-pong”, com outro diplomata como árbitro. Muitos outros colegas, devidamente trajados, acompanhavam a partida ao redor da mesa. A legenda da ilustração fazia referência aos problemas da “diplomacia dos pés”, ou seja, dos jogos de futebol internacionais como mecanismo de aproximação entre as nações. Com o sugestivo título de “Com os pés, não, com as mãos...”, a afirmação: “Entre irmãos que se estimam são mais próprias as partidas de PingPong". 46

As complicações vinham sendo de tal ordem que o deputado paulista Carlos Garcia apresentou um projeto de lei ao Congresso cujo primeiro artigo propunha a proibição da realização de jogos internacionais de futebol. Além de proibir os jogos internacionais no país, o segundo artigo do projeto mencionava: “aos quadros nacionaes de futebol que hajam de realizar partidas em paizes estrangeiros, o governo negará todos os auxílios moraes e materiaes que porventura puder conceder". ${ }^{47}$ Tal fato foi também noticiado pelo correspondente do New York Tribune no Rio de Janeiro, em pequena nota

\footnotetext{
${ }^{46}$ J. CARLOS. Com os pés, não, com as mãos... O Malho, Rio de Janeiro, ano XXI, n. 1.046, 30 set., 1922 , p. 1.

${ }^{47}$ FUTEBOL: competições internacionais. Folha da Noite, São Paulo, 4 out., 1922, p. 4.
} 
Owing to acrimonious discussion in the press, as well as several riotous outbreaks on the part of the spectators during the international football series being played here for the South American champioship, deputy Carlos Garcia has introduced a bill in the Chamber of Deputies prohibiting the playing of international football matches in Brazil. ${ }^{48}$

Cada vez mais a competição de futebol passou a ser vista como um revés no discurso pacifista que os gestores do país formulavam para sua política internacional. O abandono dos uruguaios da competição foi um exemplo contundente. Ironizando tal situação, em uma ilustração de meia página na revista $O$ Malho, sob o título “O football do futuro”, J. Carlos colocou dois diplomatas, em trajes de gala, como na capa do número anterior da mesma revista, disputando uma partida de futebol. Pequenas diferenças no acabamento de cada um dos trajes sugerem que cada um representava uma nação distinta. Ao fundo, nas gerais do estádio, presentes ao jogo, um casal abraçado e um senhor sentado comportadamente. No campo, um dos diplomatas chega próximo à meta defendida pelo seu colega. Ao lado de uma das traves, em destaque na imagem, repousa um livro grosso com o título "Bom Tom”, com uma pomba branca pousada em sua capa. O “jogador” que está com a bola pergunta ao “goleiro”: “V. Ex. dá licença? Eu desejaria marcar um goal...”. O adversário curva-se para frente e em gesto de reverência dá a passagem para o "atacante” dizendo: “Oh! Sem cerimonia! A casa é vossa...”. 49

A CBD cogitava acionar o tratamento de reciprocidade internacional com o Uruguai. Notas da Folha da Noite davam conta que os dirigentes da CBD pensavam em não enviar a seleção nacional para o campeonato sul-americano de 1923, a ser realizado em Montevideu, “como represalia e protesto á attitude tomada presentemente pela entidade superior do Uruguay”, 50 algo que não chegou a ocorrer.

Dias depois, o mesmo jornal publicava outra nota, mais extensa, avaliando a situação criada pela CBD e a Asociación Uruguaya de Fútbol (AUF). O autor da nota explorava uma situação comum no período: o da associação entre a CBD e a Liga Metropolitana de

\footnotetext{
48 “Devido à acaloradas discussões na imprensa, assim como as inúmeras confusões por parte dos espectadores durante o campeonato internacional que está sendo disputado para os Jogos Sul-Americanos, o deputado Carlos Garcia apresentou uma proposta à Câmara de Deputados proibindo a disputa de partidas internacionais de futebol no Brasil”. BRAZIL Bill Against Football. New York Tribune, Nova Iorque, 4 out., 1922, p. 14. Disponível em: <http://chroniclingamerica.loc.gov/lccn/sn83030214/1922-10-04/ed-1/seq14/; words=Brazil+Football+football?date1=1922\&rows=20\&searchType=basic\&state=\&date2=1922\&proxtext $=$ Brazil + football $\& y=0 \& x=0 \&$ dateFilterType=yearRange\&index=1>. Acesso em: 12 mar. 2011 A mesma nota também foi publicada no Evening Public Ledger (Filadelfia) no mesmo dia, na p. 20. Disponível em: $<$ http://chroniclingamerica.loc.gov/lccn/sn83045211/1922-10-04/ed-1/seq20/;words=Brazil +Football ?date1=1922\&rows=20\&searchType=basic\&state=\&date2=1922\&proxtext $=$ Brazil $+\mathrm{f}$ ootball\&y=0\&x=0\&dateFilterType=yearRange\&index=2>. Acesso em: 12 mar. 2011.

${ }^{49}$ J. CARLOS. O Football do Futuro. O Malho, Rio de Janeiro, ano XXI, n. 1.048, 14 out. 1922, p.22.

${ }^{50}$ A ATITUDE dos Uruguaios. Folha da Noite, São Paulo, 16 out., 1922, p. 4.
} 
Desportes Terrestres (LMDT), entidade que organizava os esportes terrestres no Rio de Janeiro, acusada pelos paulistas de monopolizar os altos cargos da CBD. Chamava a instituição nacional de “Confederação-Metropolitana, a mista agremiação que tem a seu cargo a direcção dos jogos ao ar livre em nossa terra”, para caracterizar que, de modo algum os paulistas, ou a entidade gestora dos esportes em São Paulo, a Associação Paulista de Sports Athleticos (APSA), tinham responsabilidade nas

represalias que, de forma alguma poderão dar resultado satisfatório para a união sul-americana. Dessa pendência, como de quaesquer outras, sahirão certamente picuinhas, as mais irritantes, ardidas pelos magnatas que sempre imperam junto das entidades superiores de esporte e, de uma vez por todas, poder-se-á considerar como uma utopia aquillo que os estadistas dos países sul-americanos procuram alcançar - uma permanente amizade. ${ }^{51}$

Sabemos que a grande imprensa paulista sempre foi muito crítica com o que se passava no Rio de Janeiro, e vice-versa. Independente dessa noção, o texto mostra claramente a visão do cronista de como os eventos desagradáveis ocorridos durante a competição (“picuinhas, as mais irritantes”) organizada por uma entidade nacional formada por um grupo de elite que se mantinha no poder ("magnatas que sempre imperam junto das entidades superiores de esporte”) não poderia trazer o objetivo máximo dos “estadistas dos países sulamericanos”: “uma permanente amizade”.

A par dos problemas diplomáticos entre Brasil e Uruguai, o título de campeão sulamericano foi efusivamente comemorado no Rio de Janeiro e em São Paulo e teve ampla cobertura da grande imprensa brasileira. ${ }^{52} \mathrm{O}$ prestígio do título foi também notícia no The New York Times, em uma pequena nota com o título "Brazil Captures Title”. 53 Dias antes, o mesmo jornal havia noticiado, também em pequena nota, que a Argentina "was the winner of the Olympic Games held in connection with the Brazilian Centennial”, referindo-se à

\footnotetext{
${ }^{51}$ FUTEBOL: arrogância em demasia”. Folha da Noite, São Paulo, 17 out., 1922, p. 4.

${ }^{52}$ Em outros trabalhos ainda em desenvolvimento foram analisados inúmeros periódicos do Rio de Janeiro e São Paulo. Os discursos da imprensa majoritariamente exaltam os feitos da seleção e associam os jogadores com as causas da nação e da defesa da pátria.

53 BRAZIL Captures Title. The New York Times, Nova Iorque, 23 out., 1922. Disponível em: <http:/query.nytimes.com/mem/archive-free/pdf?res=9C03E4DF1F39EF3ABC4B51DFB6678389639EDE >. Acesso em 12 mar., 2011. Outros jornais publicaram também pequenas notas, como o Evenig Public Ledger (Filadelfia) BRAZIL takes Football Title, 23 out. 1922, p. 22. Disponível em: $<$ http://chroniclingamerica.loc.gov/lccn/sn83045211/1922-10-23/ed-1/seq22/;words=Brazil+Football?date1=1922\&rows=20\&searchType=basic\&state=\&date2=1922\&proxtext=Brazil $+\mathrm{f}$ ootball\&y=0\&x=0\&dateFilterType=yearRange\&index=0>. Acesso em 12 mar. 2011.
} 
somatória de pontos das competições. ${ }^{54}$ Interessante notar que os jornais paulistas e cariocas não deram destaque à pontuação geral do Brasil no evento, que o colocou como segundo colocado no cômputo geral das modalidades.

No entanto, a imprensa internacional não deu destaque apenas ao evento em si, aos resultados das competições e à proposta do deputado Carlos Garcia em proibir jogos internacionais de futebol. O The New York Times enfocava a possibilidade das empresas norte-americanas investirem nas exportações de "sporting goods" para o Brasil, devido ao crescimento da prática de atividades esportivas no país. Em uma longa entrevista a W. E. Embrey, “Assistant United States Trade Commissioner” no Rio de Janeiro, publicada em 15 de setembro de 1922, dias após o início dos Jogos Sul-Americanos, o comissário colocava que "a big market for athletic goods exists in Brazil” e apontava as possibilidades de investimento no mercado de materiais esportivos para atender aos esportes mais populares do país: o futebol, o tênis e o basquetebol.

Embrey afirmava que o futebol era o esporte mais popular, e comparava-o, também, ao baseball nos Estados Unidos, e, como havia sido introduzido por ingleses, fazia da Inglaterra a grande exportadora de materiais esportivos para o Brasil. Em suas palavras

The sporting goods market in Brazil has largely been in British hands. Germany sold comparative large amounts of athletic material before the war and is making efforts to regain this trade. The United States has been falling far behind Great Britain, largely for the reason that American sporting goods have not been pushed with the same energy and effort as many other American manufactures which have gained a firm foothold in the Brazilian market. $^{55}$

A atenção para os possíveis negócios no esporte fazia parte do contexto de aproximação que os dois países passavam a adotar. Vale lembrar que foi em 1922 que o presidente Epitácio Pessoa contratou uma missão naval norte-americana “para os diversos

\footnotetext{
${ }^{54}$ ARGENTINA Wins Games. The New York Times. Nova Iorque, 18 set., 1922. Disponível em: $<$ http://query.nytimes.com/mem/archive-free/pdf?res=9B0CEEDC1139EF3ABC4052DFBF668389639EDE>. Acesso em: 12 dez. 2010.

55 “O mercado de produtos esportivos no Brasil tem estado, em sua maioria, nas mãos dos ingleses. A Alemanha vendia grandes quantidades de material atlético antes da guerra e está lutando para retomar o mercado. Os Estados Unidos tem perdido terreno pra a Inglaterra, principalmente porque os produtos esportivos americanos não têm sido empurrados com a mesma energia e esforço com que outros industriais americanos, que conquistaram pé firme no mercado brasileiro.” ATHLETIC Goods in Brazil. The New York Times. Nova Iorque, 15 set. 1922. Disponível em:

<http://query.nytimes.com/mem/archive-free/pdf?res=9802E6DF1139EF3ABC4D52DFBF668389639EDE>. Acesso em: 23 nov. 2010.
} 
serviços da Marinha de Guerra Brasileira”,56 que contava com nove oficiais superiores daquele país.

Outras notas do The New York Times também davam conta de uma aproximação das relações entre os Estados Unidos e o Brasil através do esporte. Apenas para citar dois exemplos, apresenta-se, ora, uma iniciativa em 1919 e outra em 1922. Primeiramente, a do Capitão L. L. Byrd, vencedor da prova de lançamento de disco nos Jogos Inter-Aliados de 1919, em Paris, afirmando que se mudaria para o Brasil e que planejava formar seu próprio time olímpico na América do Sul, e sugeria uma equipe de atletas sul-americanos para os Jogos Olímpicos. ${ }^{57}$ A segunda iniciativa foi a de uma jovem norte-americana de 23 anos, Carolyn Virginia Platner, que foi o Rio de Janeiro para montar uma escola de bilhar para mulheres, pois, segundo a norte-americana "há uma loucura por bilhar” na Capital Federal brasileira. $^{58}$

Nesse exemplo, pode-se ver com bastante clareza a proposta de Houlihan (op.cit., p. 20) para a análise das relações internacionais através do esporte como possibilidade de ganhos comerciais para os países. A chamada “indústria do esporte” norte-americana percebia que o estreitamento das relações com o Brasil e o crescimento das atividades esportivas neste país seriam meios importantes para a exportação tanto de materiais esportivos, quanto de iniciativas de empreender atividades esportivas comercialmente rentáveis em território brasileiro.

As relações de cordialidade entre os dois países, ainda que com pesos diferentes na balança (o Imperador brasileiro foi ao centenário de independência dos E.U.A., mas o presidente desse país não veio ao Brasil para o centenário da independência brasileira), se materializavam também nos negócios relacionados ao esporte. Se os E.U.A. eram os maiores compradores do café brasileiro, o Brasil acenava com boas possibilidades de negócio para a indústria de manufaturados e do entretenimento norte-americanas.

\footnotetext{
${ }^{56}$ BRASIL. "Relatório dos anos de 1922 e 1923 apresentado ao Presidente da República dos Estados Unidos do Brasil: Aviso do Ministério da Marinha, em 21 de Julho de 1922”. Ministério das Relações Exteriores. Rio de Janeiro: Imprensa Nacional, 1924, vol. 1, p. 204.

${ }^{57}$ TERSE News of Sports in Town and Out: to boom South American athletics. The New York Times, Nova Iorque, 17 ago. 1919. Disponível em: <http://query.nytimes.com/mem/archivefree/pdf?res=F20E15F8385910738DDDAE0994D0405B898DF1D3>. Acesso em: 15 mar. 2011.

${ }^{58}$ GIRL will open Billiard School for women in Brazil. The New York Times. Nova Iorque, 20 nov. 1922. Disponível em: $<$ http://query.nytimes.com/mem/archivefree/pdf?res=FA0814F8355A1B7A93C2AB178AD95F468285F9>. Acesso em: 15 mar. 2011.
} 


\section{Competições esportivas e relações internacionais: considerações}

Os eventos de 1919 e 1922 podem ser considerados grandes marcos iniciais de um processo mais longo de envolvimento do país com a possibilidade de sediar competições esportivas internacionais.

O papel das Relações Internacionais deve ser levado em conta na análise deste momento particularmente importante pelo qual o país passava. A maioria dos países foram bastante hábeis em capitalizar os eventos e obtiveram excelentes resultados, inclusive em sua política externa, prestígio e projeção internacional. O Brasil tem, agora, uma chance singular, como nenhum outro país do mundo jamais teve, de sediar, em um intervalo de dois anos, as duas maiores competições esportivas do mundo, a Copa do Mundo de Futebol, em 2014, e os Jogos Olímpicos, em 2016.

Ao se analisar os eventos de 1919 e 1922, pelo prisma das relações internacionais, pode-se observar as aproximações cada vez mais penetrantes do Estado com os grupos ligados à elite carioca que dirigia os esportes no país. Esses grupos criaram mecanismos de apropriação da prática esportiva e se interligaram com outros grupos da elite de outras nações que, por sua vez, apropriaram-se das práticas esportivas em seus países e se ligaram, com maior ou menor intensidade, aos governos. Criava-se assim uma rede de federações internacionais que se agrupavam em torno de uma entidade superior que geria o esporte em nível internacional.

O esporte foi traduzido, codificado e monopolizado por esse pequeno grupo que fazia com que os incentivos governamentais, econômicos e políticos fluíssem apenas para seus clubes e federações, e marginalizava todos aqueles que deixassem de seguir os modelos de práticas esportivas controladas por essas entidades. O Estado elegia tais entidades e dava a elas o título de “entidades oficiais”, responsáveis pela representação do país em competições internacionais, transformados em mega-eventos, atraindo a atenção do público e da grande imprensa. As competições esportivas internacionais ainda tinham a função de legitimizar determinados grupos da elite dos diversos países do mundo como os gestores “oficiais” do esporte em seus países.

Os agentes do governo passavam, então, a exercer suas relações internacionais através do esporte, e procuravam deixar transparecer, nas disputas, o seu discurso mais amplo de política externa. Os jornais e revistas reverberavam os acontecimentos e, mesmo quando 
faziam críticas, atestavam a importância dos esportes para a política externa do país, tanto nas pesadas críticas da Folha da Noite, quanto no humor de um J. Carlos.

De uma maneira geral, o vínculo entre sediar um evento esportivo internacional, ser campeão e atrelar tudo isso a um projeto político do Estado, é uma tarefa de complicada execução. Ser campeão e projetar a vitória como sucesso da nação pareceu ser evidente em 1919 e, principalmente, em 1922. No entanto, o esporte tem um enorme apelo emocional, principalmente para quem o pratica e para quem o assiste de maneira regular, aquele que torce. Nem tanto para quem administra. E que para uma seleção seja campeã, outras devem ser derrotadas. Até que ponto a ânsia da vitória leva os dirigentes a tomarem medidas visando à conquista dessa vitória na competição? Até que ponto tais medidas podem desagradar seus adversários? Até que ponto essas medidas não trarão prejuízos para as relações entre os governos dos diferentes países envolvidos em uma competição? Vale a pena tentar a vitória a qualquer custo?

Tais perguntas devem estar postas para os gestores desse tipo de projeto. Em 1919, os jogadores uruguaios ficaram revoltados com o árbitro que não apitou o final do jogo. Em 1922, revoltaram-se com a atuação do árbitro brasileiro, representante de um país interessado diretamente na derrota uruguaia, e abandonaram a competição e o país. Está-se diante de um contexto em que o Estado brasileiro investe altas somas no esporte de alta competição. Como o país está usando - e ainda usará - essas competições como instrumento de suas relações internacionais? De que maneira será gerenciado o projeto de vitória nessas competições? Cabe, agora, aos pesquisadores observar, analisar e apontar algumas ferramentas para se aproveitar esse momento da melhor maneira possível.

\title{
"FOOT DIPLOMACY": Brazil and the 1919 and 1922 South American sports competitions
}

\begin{abstract}
This article aims at discussing the role of the two first international sports competitions held in Brazil in 1919 and 1922 in the country's international relations scenario. By analyzing Brazilian foreign affairs, diplomatic actions and the reverberation of these events in the press, inside and outside the country, we try to make a first move to the understanding of these competitions as important steps in the country's trajectory in holding international sports events and relevant aspects of Brazilian foreign policies.
\end{abstract}

Keywords: Sports. Brazilian First Republic. International Relations. 


\section{Referências}

ANDERSON, Benedict. Comunidades Imaginadas: reflexões sobre a origem e a propagação do nacionalismo. Lisboa: Edições 70, 2005.

ARÓSTEGUI, Julio. Pesquisa Histórica: teoria e métodos. Bauru/SP: EDUSC, 2006.

BEACOM, Aaron. Sport in International Relations: a case for cross-disciplinary investigation. The Sports Historian. Exter: University of Exeter, v. 20, n. 2 , p. 1-23, 2000.

BRASIL. Ministério da Justiça e dos Negócios Interiores. "Programma para a commemoração do Centenário da Independência”. 4 de fevereiro de 1921, p.2.538.

BRASIL. Diário Official , 3 de março de 1921, p. 4.312.

BRASIL. "Relatório do Ministério das Relações Exteriores de 1922 e 1923: III- Credencial do Sr. Charles Evans Hugues na qualidade de Embaixador Extraordinário e Plenipotenciário". Anexo A, n. 48. Rio de Janeiro: Imprensa Nacional, p. 55.

BRASIL. "Relatório do Ministério das Relações Exteriores de 1922 e 1923: IV - Resposta à Carta-Credencial do Senhor Charles E. Hugues. Anexo A, n.49. Rio de Janeiro: Imprensa Nacional, p. 56.

BRASIL. "Relatório apresentado ao Presidente da Republica dos Estados Unidos do Brasil pelo Ministro das Relações Exteriores”. Rio de Janeiro: Imprensa Nacional, 1924, p. 8.

BRASIL. "Relatório dos anos de 1922 e 1923 apresentado ao Presidente da República dos Estados Unidos do Brasil: Aviso do Ministério da Marinha, em 21 de Julho de 1922”. Ministério das Relações Exteriores. Rio de Janeiro: Imprensa Nacional, 1924, vol. 1, p. 204.

BUCHANAN, Yan. “Elwoos S. Brown: Missionary Extraordinary”. Journal of Olympic History, v. 6, n. 3, p. 12-13.

BURNS, E. Bradford. As Relações Internacionais do Brasil durante a Primeira República. In: FAUSTO, Boris (dir.). História Geral da Civilização Brasileira: o Brasil Republicano. Tomo III, vol. 2. Rio de Janeiro-São Paulo: Difel, 1977.

CERVO, Amado Luiz. Relações Internacionais: formação dos conceitos brasileiros. São Paulo: Editora Saraiva, 2008.

CERVO, Amado Luiz e BUENO, Clodoaldo. História da Política Exterior do Brasil. Brasília: Editora Universidade de Brasília, 2010.

DEBORD, Guy. A Sociedade do Espetáculo. Rio de Janeiro: Contraponto, 1998.

Decreto n. 3.955. Diário Official dos Estados Unidos do Brasil, 31 de dezembro de 1919, p. 19.350 
DRUMOND, Maurício. Vargas, Perón e o esporte: propaganda política e a imagem da nação. Estudos Históricos. Rio de Janeiro: CPDOC/FGV-RJ, v. 17, n. 44, p. 398-421, 2009.

DUBY, George. A História Continua. Rio de Janeiro: Jorge Zahar Ed/ Ed. UFRJ, 1993.

ELLIS, Charles Howard. The origin, structure \& working of the League of Nations. New Jersey: The Lawbook Exchange, Ltd, $20043^{\text {a }}$ ed., p. 139-140. (1 ${ }^{\text {a }}$ edição: Boston: Houghton Mifflin Company, 1929)

FLUMINENSE FOOTBALL CLUB. Relatório dos Trabalhos Sociais concernentes ao anno de 1919. Rio de Janeiro: Papelaria Macedo, 1920.

FRANZINI, Fabio. Corações na ponta da chuteira: capítulos iniciais da história do futebol brasileiro (1919-1938). Rio de Janeiro: DP\&A Editora, 2003.

FERREIRA Marieta de Moraes. A Reação Republicana e a Crise dos Anos 20. Estudos Históricos. Rio de Janeiro: CPDOC/FGV-RJ, v. 16, n. 11, 1993.

GRAMSCI, Antonio. Os intelectuais e a organização da cultura. Rio de Janeiro: Ed. Civilização Brasileira, 1982.

HILL, Chistopher. "Prologue" in LEVERMORE and BUDD (eds.). Sport and International Relations: an emerging relationship. London and New. York: Routledge, 2004.

HOBSBAWN, Eric. “Introdução”. In: HOBSBAWN, Eric e RANGER, Terence (orgs.). A invenção das tradições. Rio de Janeiro: Paz e Terra, 2002.

HOULIHAN, Barrie, Sport and International Politics. Hemel Hempstead: Harvester Wheatsheaf, 1994.

LEVERMORE, Roger and BUDD, Adrian (eds.). Sport and International Relations: an emerging reletionship. New York: Routledge, 2004.

PEREIRA, Leonardo Affonso de Miranda. Footballmania: uma história social do futebol no Rio de Janeiro, 1902-1938. Rio de Janeiro, Nova Fronteira, 2000.

Recenseamento do Brasil realizado em $1^{\circ}$ de setembro de 1920. Rio de Janeiro: Typographia da Estatística, 1922.

SANTOS, João Manuel Casquinha Malaia. Revolução Vascaína: a profissionalização do futebol e a inserção sócio-econômica de negros e portugueses no Rio de Janeiro(1915 1934). Tese de Doutorado defendida no Programa de Pós Graduação em História Econômica - DH/FFLCH, Universidade de São Paulo. São Paulo, 2010.

SOUZA, Maria do Carmo Campello de. O Processo Político-partidário na Primeira República. In: MOTA, Carlos Guilherme. Brasil em Perspectiva. Rio de Janeiro- São Paulo: Difel, 1979, p. 162-226.

VIZENTINI, Paulo Fagundes. Relações Exteriores do Brasil (1930-1964): o nacionalismo, da Era Vargas à Política Externa Independente. Petrópolis: Ed. Vozes, 2009. 
Periódicos:

\section{A Cigarra}

Careta

Evening Public Ledger

Folha da Noite

Fon-Fon

Jornal do Commercio

New York Tribune

O Imparcial

O Malho

Revista Para Todos

The Corpus Christi Caller

The Evening Missourian

The New York Times

Recebido em: 30/05/2011

Aprovado em: 05/08/2011 